\title{
Hromadžić, Azra 2015. Citizens of an Empty Nation: Youth and State-Making in Postwar Bosnia-Herzegovina. Philadelphia, PA: University of Pennsylvania Press. 239 pp. Cloth: £39.00, ISBN: 9780812247008 .
}

Azra Hromadžić's ethnography of the Mostar Gymnasium, the prestigious high school in Mostar which had been divided into separate Croat and Bosniak schools during the Bosnian conflict and legally reintegrated shortly before she began her fieldwork in 2005 , traces the micropolitics of citizenship, reconstruction and ethnicity in post-war, post-socialist BosniaHerzegovina on almost every page. Its series of analytical lenses begins with the ethnicized symbolism of language in the most routine of classroom settings and moves gradually towards how the very notions of 'the people' and 'the state' have been emptied out by and since the Dayton Peace Agreement. Among its many ethnographic vignettes, perhaps the most symbolic is the set of early encounters that lent their name to one chapter, 'Bathroom Mixing': that in a school which has been officially reintegrated but has still had to run separate Croat and Bosniak curricula, the only available site for students to interact outside these sanctioned monoethnic spaces is during break, when - without even a café facility as a common space - students from the two streams are able to meet up and spend time smoking in the bathroom.

The bathroom vignette could itself stand as a telling microcosm for the Dayton Peace Agreement: a system which (in the eyes of Hromadžić and many other recent critics of Dayton ethnopolitics, such as Asim Mujkić or Jasmin Mujanović) has depoliticized Bosnian society by rewarding political and economic elites whose vested interests lie in maintaining the division of Bosnia-Herzegovina into structurally monoethnic entities and cantons. 'The lack of transethnic spaces of sociality, sharing, exchange, and everyday communication in Mostar', Hromadžić emphasises, constrains what attempts to overcome the 'podjela u glavi' 
('division in [our] heads') residents of Mostar might try to make (pp. 113-14). Yet the achievement of Citizens of an Empty Nation - perhaps no small thing in an anthropology of disempowerment - is to acknowledge locations of contingent agency where people improvise more satisfactory social orders through 'messy everyday negotiations and identifications' ( $\mathrm{p}$. 13) even though the conditions for sustaining these are not being met. While the analysis is grounded in the specifics of Bosnian politics throughout, the problems of ethnopolitical division of urban space and of institutionalized attempts at 'peacebuilding' and 'statemaking' after armed conflict have parallels around the world. The book is as much an anthropology of international intervention as of ethnic division; indeed, it is an anthropology that shows how international intervention may exacerbate ethnic division, and as such deserves a wide readership among those interested in the 'local' or 'everyday' dimensions of post-conflict peacebuilding and ethnopolitical reconciliation.

At the same time, Hromadžić's analysis gives powerful weight to the critiques of the Dayton settlement that ethnographers, along with critical geographers, have been in the forefront of articulating. If geographers such as Jeremy Crampton and David Campbell were warning very shortly after Dayton that its 'singular cartographic delineation of territory' would leave transethnic spaces, so necessary for facilitating everyday sociability, literally 'unmappable' (p. 74), Hromadžić shows what this unmappability has meant in practice: spaces where teachers congregate at ethno-linguistically separate lunch tables as routine, students have different holidays and proms, an expensively-refurbished computer room goes almost unused because the international donors' stipulation that it only be used for joint teaching could hardly ever be met, and the city outside is no better served for non-ethnicallycoded social space than the school.

This is not to argue for a simplistic narrative of multiethnic coexistence in BosniaHerzegovina, which representatives of international organisations have sometimes imagined 
as a potential source of resilience; Hromadžić shows that this narrative too has cast Bosnians as narrowly ethnic subjects, and that the very idea of the 'narod' or 'people' has been flattened out by domestic and international fixings of ethnic subjectivity. Instead, the book demonstrates what can be gained from centring the production of what Rogers Brubaker and Frederick Cooper have termed 'groupness' (p. 109, reviewer's emphasis) - a practical example of how to study, to borrow a title from Brubaker, ethnicity without groups. It demonstrates, simultaneously, what is lost when 'the fluid moments of commonality' around socio-economic hardship and political disempowerment stay invisible 'because these voices, sentiments, and experiences have [...] no institutional space to claim or that would claim them' (p. 185). Hromadžić has stayed in contact with the Mostar Gymnasium, in person and virtually, since 2006. By the time she was writing the book, protestors in the largest public mobilisation against the post-Dayton elite to date were demonstrating with slogans including 'Gladni smo na tri jezika' ('We are hungry in three languages'), implying the futility of expecting ethnopolitics to bring material improvements to Bosnians' lives; after some intensive lobbying at municipal and cantonal level, the school had finally managed to create a - still constrained - joint class to use the computer lab; and teenagers, for want of any more structured space of transethnic exchange, were still smoking in the bathroom.

\section{CATHERINE BAKER}

University of Hull 